\title{
L'esthétique et le sacré : l'icone dans la pensée spéculative et dans la vie quotidienne
}

Maria Zoubouli

\section{OpenEdition}

\section{Journals}

Édition électronique

URL : http://journals.openedition.org/etudesbalkaniques/369

ISSN : 2102-5525

Éditeur

Association Pierre Belon

Édition imprimée

Date de publication : 1 janvier 1995

Pagination : $71-102$

ISBN : 2-910860-01-9

ISSN : 1260-2116

\section{Référence électronique}

Maria Zoubouli, «L'esthétique et le sacré : l'icone dans la pensée spéculative et dans la vie

quotidienne », Études balkaniques [En ligne], 2 | 1995, mis en ligne le 08 avril 2009, consulté le 06 mai 2019. URL : http://journals.openedition.org/etudesbalkaniques/369

Ce document a été généré automatiquement le 6 mai 2019.

Tous droits réservés 


\section{L'esthétique et le sacré : l'icone dans la pensée spéculative et dans la vie quotidienne}

Maria Zoubouli

\section{NOTE DE L'AUTEUR}

Nous adoptons ici l'orthographe du mot icone proposée par B. bouvier ans M. Lazovic, Icones d'une collection privée de Genève 1974, p. 7-9. Par ailleurs, nous entendons par « icone » non seulement les panneaux mobiles mais aussi les mosaïques et les fresques.

\section{AUTEUR}

MARIA ZOUBOULI

P.R.I. Pierre Belon 